\title{
Symptomatic adrenal insufficiency during inhaled corticosteroid treatment
}

\author{
L Patel, J K Wales, M S Kibirige, A A Massarano, J M Couriel, P E Clayton
}

\begin{abstract}
Symptomatic adrenal insufficiency, presenting as hypoglycaemia or poor weight gain, may occur on withdrawal of corticosteroid treatment but has not previously been reported during inhaled corticosteroid treatment. This case series illustrates the occurence of clinically significant adrenal insufficiency in asthmatic children while patients were on inhaled corticosteroid treatment and the unexpected modes of presentation. General practitioners and paediatricians need to be aware that this unusual but acute serious complication may occur in patients treated with inhaled corticosteroids.

(Arch Dis Child 2001;85:330-334)
\end{abstract}

Keywords: adrenal insufficiency; inhaled corticosteroid; asthma; hypoglycaemia

Impaired linear growth and hypothalamicpituitary-adrenal (HPA) suppression on biochemical testing are recognised systemic effects of inhaled corticosteroids (ICS) in doses $\leqslant 400$ $\mu \mathrm{g} /$ day. ${ }^{12}$ In addition, a Cushingoid appearance with central obesity and fatigue have been reported with high doses. ${ }^{34}$ Features of adrenal insufficiency, such as hypoglycaemia and weight loss, may occur on withdrawal of exogenous ICS treatment. ${ }^{5}$ Despite HPA suppression, symptomatic adrenal insufficiency does not occur during treatment with pharmacological doses (exceeding physiological cortisol secretion) and has not previously been reported during treatment with subpharmacological doses as delivered by the inhaled route. The aim of this case series is to describe the occurence of clinically significant adrenal insufficiency in association with HPA suppression in asthmatic children while patients were on ICS treatment, and the unexpected modes of presentation.

\section{Case series}

CLINICAL FEATURES AT PRESENTATION

Between January 1997 and March 1999, eight children (five boys, three girls; median age 6.9 years, range 4.5-10.0) with varied presentations came to the attention of specialists at three paediatric endocrine services in the north of England. They were identified on clinical assessment and biochemical testing to have adrenal insufficiency and HPA suppression. Table 1 summarises their clinical features at presentation and results of biochemical tests. All had mild to moderately severe asthma, were managed by general practitioners or general paediatricians, had responded clinically to ICS treatment, and were deemed to be compliant with their treatment. Case 4 had coexisting allergic rhinitis and had received budesonide nasal spray $400 \mu \mathrm{g} /$ day for six months. The remaining cases had not received corticosteroids by any other route in the six months prior to presentation. None had received prolonged courses of systemic corticosteroids at any time. No patient had hyperpigmentation.

Cases 1 and 2 presented acutely with hypoglycaemia while receiving treatment with inhaled fluticasone. Their treatment had not been suddenly withdrawn prior to presentation. Neither patient had an acute intercurrent illness nor other stressful event at the time of presentation. Metabolic and other endocrine causes of hypoglycaemia were excluded by biochemical investigations (normal values of urine organic acid profile and blood acyl carnitine, insulin and $\mathrm{C}$ peptide at the time of hypoglycaemia, growth hormone, thyroxine, and TSH) and subsequent progress.

The presentation in the remaining patients was insidious. Notable features in cases 3-6 were poor weight gain while patients were receiving ICS treatment. This was associated with poor growth in height in cases $4-6$. These features were not caused by uncontrolled asthma, coexisting systemic disease, or other endocrine abnormality. In addition to poor growth in height, case 7 had hirsutism with no other endocrine abnormality and case 8 had recurrent headaches but no head and neck or neurological abnormalities.

INVESTIGATION RESULTS AT PRESENTATION HPA suppression was identified by: (1) low basal plasma cortisol (all cases); and (2) impaired response to standard dose ACTH (Synacthen) test (cases 1-5, 8) or low 24 hour urine cortisol metabolites (cases 6,7) (table 1). The pituitary-adrenal axis was unresponsive to stimulation with corticotrophin releasing factor (CRF) at presentation in cases 1,3 , and 4 (plasma cortisol $<20 \mathrm{nmol} / 1$ and plasma 
Table 1 Clinical features of adrenal insufficiency in eight patients identified to have hypothalamic-pituitary-adrenal suppression during inhaled corticosteroid treatment

\begin{tabular}{|c|c|c|c|c|c|c|}
\hline Case, sex & $\begin{array}{l}\text { Clinical features at presentation } \\
\text { (age) }\end{array}$ & Age in $y$ & $\begin{array}{l}\text { Height in } \mathrm{cm} \\
(S D S)\end{array}$ & $\begin{array}{l}\text { Weight in } \mathrm{kg} \\
(S D S)\end{array}$ & $\begin{array}{l}\text { HPA function at presentation } \\
\text { (plasma cortisol in nmol/l) }\end{array}$ & $\begin{array}{l}\text { Inhaled corticosteroid, daily dose } \\
\left(\text { dose/ } \mathrm{m}^{2} / \text { day }\right) \text { device; duration }\end{array}$ \\
\hline \multirow[t]{2}{*}{$1, M$} & \multirow[t]{2}{*}{$\begin{array}{l}\text { Acute: unconscious, plasma } \\
\text { glucose } 0.9 \mathrm{mmol} / 1(4.5 \mathrm{y})\end{array}$} & 4.5 & $98.2(-2.0)$ & $14.1(-2.1)$ & \multirow[t]{2}{*}{$\begin{array}{l}\text { Plasma cortisol } 100 \text { at } 0800^{\star} \text {, } \\
\text { SDST peak } 200\end{array}$} & \multirow[t]{2}{*}{$\begin{array}{l}\text { Fluticasone } 500 \mu \mathrm{g} / \text { day }(780 \\
\mu \mathrm{g} / \mathrm{m}^{2} / \text { day) volumatic; } 6 \mathrm{mth}\end{array}$} \\
\hline & & 6.3 & $108.5(-1.8)$ & $18.6(-1.1)$ & & \\
\hline \multirow[t]{3}{*}{$2, \mathrm{~F}$} & \multirow[t]{3}{*}{$\begin{array}{l}\text { Acute: drowsy, disoriented and } \\
\text { headache for } 24 \mathrm{~h} \text {, plasma } \\
\text { glucose } 0.7 \mathrm{mmol} / \mathrm{l} \text {. Also had } \\
\text { poor growth in height and } \\
\text { weight for } 12 \mathrm{mth}(5.8 \mathrm{y})\end{array}$} & 4.8 & $104.0(-0.7)$ & $17.0(-0.3)$ & \multirow[t]{3}{*}{$\begin{array}{l}\text { Plasma cortisol } 30 \text { at } 0900^{\star} \text {, } \\
\text { SDST peak } 30\end{array}$} & \multirow[t]{3}{*}{$\begin{array}{l}\text { Budesonide } 400 \mu \mathrm{g} / \text { day }(570 \\
\mu \mathrm{g} / \mathrm{m}^{2} / \text { day) nebuhaler; } 15 \mathrm{mth} \text {, } \\
\text { followed by fluticasone } 500 \mu \mathrm{g} / \text { day } \\
\left(705 \mu \mathrm{g} / \mathrm{m}^{2} / \text { day) volumatic; } 4 \mathrm{mth}\right.\end{array}$} \\
\hline & & 5.8 & $106.0(-1.7)$ & $17.0(-1.2)$ & & \\
\hline & & 7.0 & $119.7(-0.3)$ & $24.4(0.4)$ & & \\
\hline \multirow[t]{3}{*}{$3, \mathrm{M}$} & \multirow[t]{3}{*}{$\begin{array}{l}\text { Insidious: weight loss and } \\
\text { listlessness for } 3 \mathrm{mth}(4.5 \mathrm{y})\end{array}$} & 4.2 & $97.8(-1.5)$ & $15.1(-1.0)$ & \multirow[t]{3}{*}{$\begin{array}{l}\text { Plasma cortisol } 100 \text { at } 0830^{\star} \text {, } \\
\text { SDST peak } 20\end{array}$} & \multirow[t]{3}{*}{$\begin{array}{l}\text { Fluticasone } 500 \mu \mathrm{g} / \text { day }(770 \\
\mu \mathrm{g} / \mathrm{m}^{2} / \text { day) volumatic; } 6 \mathrm{mth}\end{array}$} \\
\hline & & 4.7 & $101.1(-1.5)$ & $14.9(-1.7)$ & & \\
\hline & & 7.0 & $118.5(-0.6)$ & $22.5(-0.1)$ & & \\
\hline \multirow[t]{3}{*}{$4, M$} & \multirow[t]{3}{*}{$\begin{array}{l}\text { Insidious: poor growth in height } \\
\text { and weight for } 2 \mathrm{y}(8.0 \mathrm{y})\end{array}$} & 5.8 & $109.0(-1.1)$ & $18.5(-0.7)$ & \multirow[t]{3}{*}{$\begin{array}{l}\text { Plasma cortisol }<20 \text { at } 0900^{\star}, \\
\text { SDST peak }<20\end{array}$} & \multirow[t]{3}{*}{$\begin{array}{l}\text { Fluticasone } 500 \mu \mathrm{g} / \text { day }(610 \\
\mu \mathrm{g} / \mathrm{m}^{2} / \text { day) volumatic; } 4.5 \mathrm{y}\end{array}$} \\
\hline & & 8.0 & $114.6(-2.4)$ & $21.2(-1.4)$ & & \\
\hline & & 9.7 & $126.7(-1.6)$ & $30.9(0.1)$ & & \\
\hline \multirow[t]{3}{*}{$5, M$} & \multirow[t]{3}{*}{$\begin{array}{l}\text { Insidious: poor growth in height } \\
\text { and weight for } 12 \mathrm{mth}(10.0 \mathrm{y})\end{array}$} & 9.0 & $121.9(-2.0)$ & $22.1(-1.9)$ & \multirow[t]{3}{*}{$\begin{array}{l}\text { Plasma cortisol } 90 \text { at } 0900^{\star} \text {, } \\
\text { SDST peak } 300\end{array}$} & \multirow[t]{3}{*}{$\begin{array}{l}\text { Beclomethasone dipropionate } 600 \\
\mu \mathrm{g} / \text { day }\left(690 \mu \mathrm{g} / \mathrm{m}^{2} / \text { day }\right) \text { dischaler; } 3 \mathrm{y}\end{array}$} \\
\hline & & 10.0 & $125.0(-2.2)$ & $23.3(-2.2)$ & & \\
\hline & & 11.2 & $130.6(-2.0)$ & $26.9(-1.8)$ & & \\
\hline \multirow[t]{3}{*}{$6, \mathrm{~F}$} & \multirow[t]{3}{*}{$\begin{array}{l}\text { Insidious: poor growth in height } \\
\text { and weight for } 2 \mathrm{y}(9.8 \mathrm{y})\end{array}$} & 6.1 & $110.7(-1.0)$ & $17.1(-1.4)$ & \multirow[t]{3}{*}{$\begin{array}{l}\text { Plasma cortisol } 162 \text { at } 0900^{\star} \text {; } \\
24 \mathrm{~h} \text { urine cortisol } \\
\text { metabolites low }(\text { THC } 380 \\
\mu \mathrm{g} \text {, THE } 70 \mu \mathrm{g} \text { ) }\end{array}$} & \multirow[t]{3}{*}{$\begin{array}{l}\text { Budesonide } 400 \mu \mathrm{g} / \text { day ( } 505 \\
\mu \mathrm{g} / \mathrm{m}^{2} / \text { day) nebuhaler; } 5 \mathrm{y}\end{array}$} \\
\hline & & 9.3 & $120.0(-2.4)$ & $18.8(-3.2)$ & & \\
\hline & & 11.3 & $137.0(-1.2)$ & $27.6(-1.7)$ & & \\
\hline \multirow[t]{3}{*}{$7, \mathrm{M}$} & \multirow[t]{3}{*}{$\begin{array}{l}\text { Insidious: poor growth in height } \\
\text { and hirsutism for } 6 \mathrm{mth}(5.6 \mathrm{y})\end{array}$} & 4.8 & $99.6(-1.9)$ & $16.0(-1.1)$ & \multirow[t]{3}{*}{$\begin{array}{l}\text { Plasma cortisol }<20 \text { and } 30 \text { at } \\
0900^{\star} ; 24 \mathrm{~h} \text { urine cortisol } \\
\text { metabolites undetectable } \dagger\end{array}$} & \multirow[t]{3}{*}{$\begin{array}{l}\text { Budesonide } 400 \mu \mathrm{g} / \mathrm{day}(595 \\
\mu \mathrm{g} / \mathrm{m}^{2} / \text { day) nebuhaler; } 12 \mathrm{mth}\end{array}$} \\
\hline & & 5.6 & $101.5(-2.5)$ & $17.1(-1.2)$ & & \\
\hline & & 6.7 & $111.5(-1.6)$ & $19.6(-1.0)$ & & \\
\hline \multirow[t]{3}{*}{$8, \mathrm{~F}$} & \multirow[t]{3}{*}{$\begin{array}{l}\text { Insidious: poor growth in height } \\
\text { and headaches for } 12 \mathrm{mth}(8.4 \\
\text { y) }\end{array}$} & 7.2 & $116.0(-1.2)$ & $21.0(-0.7)$ & \multirow[t]{3}{*}{$\begin{array}{l}\text { Plasma cortisol } 33 \text { at } 0900^{\star} \text {, } \\
\text { SDST peak } 325\end{array}$} & \multirow[t]{3}{*}{$\begin{array}{l}\text { Fluticasone } 1000 \mu \mathrm{g} / \text { day }(1136 \\
\mu \mathrm{g} / \mathrm{m}^{2} / \text { day) volumatic; } 18 \mathrm{mth}\end{array}$} \\
\hline & & 8.5 & $119.5(-1.9)$ & $23.5(-0.8)$ & & \\
\hline & & 10.1 & $128.0(-1.6)$ & $33.9(0.2)$ & & \\
\hline
\end{tabular}

Rows in bold represent measurements after the diagnosis of adrenal insufficiency.

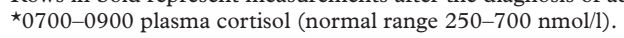

$\dagger 24 \mathrm{~h}$ urine cortisol metabolites: THC, tetrahydrocortisol (normal range 500-1300 $\mu \mathrm{g}$ ); THE, tetrahydrocortisone (normal range 200-550 $\mu \mathrm{g}$ ).

SDST, standard dose Synacthen (ACTH) test (criterion for normal response is peak plasma cortisol $>500 \mathrm{nmol} / \mathrm{l}$ ).

ACTH $<5 \mathrm{pmol} / 1$ at all time points). In the patients who had ultrasound examination of the abdomen, the adrenal glands appeared normal in cases 1,3 , and 7 but could not be identified in case 4 . Autoantibody screen was negative in all.

MANAGEMENT AND PROGRESS

The dose of ICS at presentation did not exceed that recommended in step 3 of the British Thoracic Society Guidelines in seven of these eight cases (case 8 was the exception). ${ }^{6}$ However, only two patients (cases 6 and 7) were receiving medication within the licenced prescription (beclomethasone $400 \mu \mathrm{g} /$ day, fluticasone $200 \mu \mathrm{g} /$ day, and budesonide 800 $\mu \mathrm{g} /$ day). Case 2 had received fluticasone 1500 $\mu \mathrm{g} /$ day for four weeks, $1000 \mu \mathrm{g} /$ day for four weeks, and $500 \mu \mathrm{g} /$ day for eight weeks prior to presentation. We are not aware of other patients receiving higher doses of ICS than those mentioned in table 1 .

The management of adrenal insufficiency included: (1) informing parents about a potential adrenal crisis, management of acute stressful events, and precautions necessary to prevent this emergency; and (2) training parents to manage an acute adrenal crisis and providing open access to the hospital accident and emergency department. Daily hydrocortisone replacement (physiological dose $12 \mathrm{mg}$ / $\mathrm{m}^{2}$ /day orally, with two thirds of the dose in the morning and one third in the evening) was indicated in patients who presented with hypoglycaemia (cases 1 and 2) and those with no adrenocortical reserve (cases 3 and 4, and case 7 for 18 months). In the remaining patients, hydrocortisone replacement was reserved for acute stressful events. Patients were reviewed at four to eight weekly intervals and an attempt was made to gradually reduce the dose of ICS while simultaneously maintaining adequate control of asthma symptoms. Biochemical tests of HPA axis function were repeated after successful reduction in dose of ICS or gradual withdrawal of treatment. Any ICS treatment and hydrocortisone replacement were withheld for 24 hours prior to testing.

Normal ACTH test responses and 24 hour urine cortisol metabolites were obtained in four cases after: (1) gradual withdrawal of ICS with salmeterol (case 7 over 18 months when hydrocortisone was also discontinued) or without salmeterol (case 8 over three months); and (2) change in ICS preparation without salmeterol (case 5 from beclomethasone $600 \mu \mathrm{g} /$ day to budesonide $200 \mu \mathrm{g}$ /day over six months) or with addition of salmeterol (case 6 from budesonide $400 \mu \mathrm{g} /$ day to fluticasone 250 $\mu \mathrm{g} /$ day over three months). Fluticasone was discontinued in case 3 after two years. Subsequent biochemical tests showed some recovery of HPA function (Synacthen test peak 
Table 2 Growth data showing poor growth in height and weight at presentation and subsequent catch up

\begin{tabular}{lll}
\hline & Before presentation & At follow up \\
\hline Median (range) time, $y$ & $1.0(0.5-3.2)$ & $1.7(1.1-2.3)$ \\
Mean (SD) change in height SDS & $-0.7(0.5)$ & $0.7(0.5)$ \\
$\quad(\mathrm{p}$ with $t$ test) & $(\mathrm{p}=0.01)$ & $(\mathrm{p}=0.003)$ \\
Mean (SD) change in weight SDS & $-0.7(0.6)$ & $1.1(0.6)$ \\
$\quad(\mathrm{p}$ with $t$ test) & $(\mathrm{p}=0.03)$ & $(\mathrm{p}=0.001)$ \\
\hline
\end{tabular}

plasma cortisol $400 \mathrm{nmol} / \mathrm{l}$ ) and his dose of oral hydrocortisone is currently being reduced. The remaining cases have continued to require oral hydrocortisone replacement for over three years despite some alterations to their ICS treatment and salmeterol (case 1 from fluticasone $500 \mu \mathrm{g} /$ day to budesonide $300 \mu \mathrm{g} /$ day; case 2 from fluticasone $500 \mu \mathrm{g} /$ day to budesonide $400 \mu \mathrm{g} /$ day; case 4 from fluticasone 500 $\mu \mathrm{g} /$ day to budesonide $800 \mu \mathrm{g} /$ day).

Catch up growth in weight and height (table 2) was observed in all patients: with hydrocortisone replacement (cases 1-4, 7), ICS withdrawal (cases 3, 7, and 8) and change in ICS preparation (cases 5 and 6 ).

\section{Discussion}

As exogenous corticosteroids cause greatest suppression of ACTH secretion, it may be difficult to differentiate from isolated ACTH or CRF deficiency, particularly when the corticosteroid dose is in the normal range. Not only are the latter extremely uncommon, but the time course of events in relation to ICS treatment in our patients makes isolated ACTH or CRF deficiency less likely. The absence of troublesome asthma symptoms when growth was impaired and subsequent catch up growth after the diagnosis and management of adrenal insufficiency excludes uncontrolled asthma as an explanation for the poor growth and is highly suggestive of reversal of adrenal insufficiency induced by ICS treatment. Impaired growth in height is a feature of Cushing's syndrome secondary to excess exogenous ICS, ${ }^{34}$ a recognised systemic effect of conventional doses of ICS ${ }^{12}$ and also a sign of adrenal insufficiency. However, the key to differentiation is increased or normal weight gain in the former and poor weight gain/weight loss in adrenal insufficiency.

This case series highlights an unrecognised paradoxical complication during ICS treatment with doses within current recommended guidelines. ${ }^{6}$ All patients were symptomatic but the presenting features were varied and unexpected: features of adrenal insufficiency (poor weight gain, hypoglycaemia) predominated over well known peripheral effects of excess exogenous corticosteroids (iatrogenic Cushing's syndrome). Our observations and the large reported range of effects on linear growth and HPA function, ${ }^{17}$ and occurrence of adverse effects with doses of ICS normally considered to be safe ${ }^{89}$ illustrate variations in individual sensitivity to corticosteroids. In addition, corticosteroid sensitivity is also likely to vary between different target tissues, and a lack of correspondence between different corticosteroid effects has been reported in healthy and non-asthmatic adults. ${ }^{10-12}$ Differential tissue sensitivity has also been proposed as an explanation for those patients with asthma who fail to respond to corticosteroid treatment but who have systemic effects. ${ }^{13}$ In our cases, it is likely that the systemic bioavailability of ICS was sufficient to suppress the HPA axis but not adequate enough to provide physiological corticosteroid replacement and thus prevent symptoms of hypoadrenalism. This, along with differential tissue sensitivity explains the predominant features of adrenal insufficiency, including hypoglycaemia, listlessness, and poor weight gain with poor growth in height.

Adrenal insufficiency, irrespective of cause, is one of the acute life threatening emergencies in paediatric practice. General practitioners and paediatricians need to be aware that it may occur in patients treated with ICS and of the unusual modes of presentation to provide timely management. Although the daily dose of ICS for seven of the eight cases might not be considered excessive, all patients were small (weight and height SD scores <0) and consequently their dose per $\mathrm{m}^{2}$ body surface area was relatively higher. Evidence based guidelines with doses of ICS recommended according to body surface area are needed. The differing potencies of the various ICS preparations, including the widely accepted 2:1 ratio between fluticasone and other ICS preparations, also needs to be taken into account. We emphasise that the distribution of the ICS preparations used in our small series should not be extrapolated to that used in the general population. Furthermore, as our patients had well controlled asthma, an attempt should have been made to reduce their dose of ICS treatment during the period before presentation. ${ }^{6}$ Failure to do so was a possible risk factor for adrenal suppression. Alternative treatments such as salmeterol and leukotriene receptor antagonists may have a role in patients who do not respond to conventional doses of ICS. Although all our patients were deemed to be compliant with their treatment, failure to take treatment and sudden withdrawal are additional risk factors for acute adrenal crisis. ${ }^{5}$

When using ICS in the management of asthma, there is a clear need to be ever cautious, as a few children as outlined in this series can get serious systemic effects, such as hypoglycaemia secondary to adrenal insufficiency, that cannot readily be predicted. As growth and weight failure was an important feature of our cases, we must emphasise the importance of growth monitoring for all children on ICS. If growth failure is detected, adrenal insufficiency should be considered and investigated with dynamic tests of adrenal function.

1 Lipworth BJ. Systemic adverse effects of inhaled corticosteroid therapy. A systematic review and meta-analysis. Arch Intern Med 1999;159:941-55.

2 Price J. The role of inhaled corticosteroids in children with asthma. Arch Dis Child 2000;82(suppl II):ii10-ii14.

3 Todd G, Dunlop K, McNaboe J, et al. Growth and adrenal suppression in asthmatic children treated with high-dose fluticasone propionate. Lancet 1996;348:27-9. 
4 Duplantier JE, Nelson RP, Morelli AR, et al. Hypothalamicpituitary-adrenal axis suppression associated with the use of inhaled fluticasone propionate. F Allergy Clin Immuno 1998;102:699-700.

5 Zwaan CM, Odink RJH, Delemarre-van de Waal HA, Dankert-Roelse JE. Acute adrenal insufficiency after discontinuation of inhaled corticosteroid therapy. Lancet 1992;340:1289-90

6 The British Guidelines on Asthma Management. 1995 Review and Position Statement. Thorax 1997;52 (supp 1):S1-S21.

7 Chrousos GP, Harris AG. Hypothalamic-pituitary-adrenal axis suppression and inhaled corticosteroid therapy. 2 . Review of literature. Neuroimmunomodulation 1998;5:288308.

8 Thomas BC, Stanhope R, Grant DB. Impaired growth in children with asthma during treatment with conventional doses of inhaled corticosteroids. Acta Paediatr 1994;83: 196-9.

9 Zimmerman B, Gold M, Wherrett D, Hanna AK. Adrenal suppression in two patients with asthma treated with low doses of the inhaled steroid fluticasone propionate. $\mathcal{F}$ Allergy Clin Immunol 1998;101:425-6.

10 Ebrecht M, Buske-Kirschbaum A, Hellhammer D, et al. Tissue specificity of glucocorticoid sensitivity in healthy adults. F Clin Endocrinol Metab 2000;85:3733-9.

11 Panarelli M, Holloway CD, Fraser R, et al. Glucocorticoid receptor polymorphism, skin vasoconstriction, and other metabolic intermediate phenotypes in normal human subjects. $\mathcal{F}$ Clin Endocrinol Metab 1998;83:1846-52.

12 Walker BR, Best R, Shackleton $\mathrm{CH}$, et al. Increased vasoconstrictor sensitivity to glucocorticoids in essential hypertension. Hypertension 1996;27:190-6.

13 Barnes PJ, Adcock IM. Steroid resistance in asthma. $Q \mathcal{F}$ Med 1995;88:455-68.

\section{Commentary}

When inhaled corticosteroid (ICS) therapy was introduced to clinical practice, it was at a time when the therapeutic options for asthma prophylaxis were limited to theophylline and sodium cromoglycate, and many asthmatic children were still on regular oral corticosteroids. Early searches for side effects from ICS gave uniformly reassuring results, and the new treatment was welcomed as a safe and effective alternative to ${ }^{1}$ and substitute for ${ }^{2}$ oral prednisolone, even when high dose ICS was necessary. ${ }^{3}$ The adrenal atrophy reported at autopsy in asthmatic children who had died while on $\mathrm{ICS}^{4}$ was widely attributed to concomitant treatment with systemic corticosteroids, and the report was discounted.

This honeymoon period was not to last for long. The first side effect to be noted was oropharyngeal moniliasis, and since then ICS therapy has been shown to be capable of producing most of the features of glucocorticoid excess. In a recent review of 163 consecutive children aged 9 years of age or above admitted with intractable asthma to the National Jewish Hospital in Denver, Covar and colleagues $^{5}$ found that even in the half who were not already on regular systemic corticosteroids, but were on high dose ICS, there was a high prevalence of corticosteroid side effects, including hypertension, Cushingoid features, adrenal suppression, myopathy, osteopenia, growth suppression, obesity, hypercholesterolaemia, cataracts, and growth retardation.

Adverse effects on carbohydrate metabolism have been noted in some studies, with raising of the insulin:glucose ratio on high dose ICS, ${ }^{6}$ and a slight decline in oral glucose tolerance. ${ }^{7}$ In contrast, it has also been reported that the reduction of stress may have beneficial effects on carbohydrate metabolism when asthma is controlled by ICS. ${ }^{8}$

A common feature in reports from the mid1980s onwards has been dose related adrenal suppression, ${ }^{9-13}$ a side effect that has generally been regarded as benign, representing nothing more than a physiological response to exogenous corticosteroid. Clinical symptoms of hypoadrenalism have not appeared to be a problem. It is therefore surprising that after more than a quarter of a century's relatively trouble free use of ICS, Patel et al should report no fewer than eight cases of clinically significant adrenal suppression in children on ICS therapy.

In two cases there was acute hypoglycaemia, not apparently caused by the sudden withdrawal of ICS, though this is the explanation that springs most readily to mind. These two cases are particularly worrying, suggesting that acute adrenal insufficiency can occur even when the child is still taking the exogenous corticosteroid that caused the adrenal insufficiency in the first place. Clearly, paediatricians will have to be vigilant in investigating asthmatic children with disturbed consciousness, unusual behaviour, or autonomic symptoms suggestive of hypoglycaemia. In addition, given the lingering suspicion that the ICS treatment must have been discontinuous (if not indeed discontinued), prescribers of ICS must emphasise the importance of compliance, and ensure that when treatment is successful, it is stepped down gradually rather than stopped suddenly.

The other cases presented insidiously, five with impaired growth over periods ranging from six months to two years. In only one did the ICS dose exceed current recommendations.

The authors are quite clear that the asthma was well controlled in these children, and this might have played a part in ensuring the systemic absorption of what are unremarkable doses of ICS. The systemic effects of budesonide and fluticasone reflect mainly lung bioavailability, ${ }^{14}$ and it has been shown that the systemic bioavailability of ICS is greater in subjects with healthy airways than in asthmatics. ${ }^{15} 16$ Thus, if in these cases the doses of ICS were greater than was strictly necessary, enhanced systemic absorption might have ensued, although a logical extension of this argument would be that perfect control is an undesirable end point for ICS therapy.

Perhaps we should have advised against the inclusion of case 7 , whose presenting features included hirsutism, hardly a feature of simple adrenal suppression. His body mass index was rather better than in the others, and he may well have had some other endocrine abnormality. However, none was found and on balance we decided that all eight cases should be included.

We can only guess at the prevalence of clinically significant adrenal suppression in children on ICS, but clearly we can no longer claim that it is non-existent. Nor can we be sure that the distribution of the individual corticosteroid molecules used by these children is anything other than a chance phenomenon. The authors are rightly cautious in refusing to comment. But it can hardly pass unnoticed that only one of these eight children was on beclomethasone, 
whereas the others were on what are sometimes described as second or even third generation ICS. Beclomethasone was the first and is still the most widely used ICS in the UK. In England in 1998, 8.43 million NHS prescriptions were filled for beclomethasone, compared to only 1.88 million for budesonide and 1.54 million for fluticasone. ${ }^{17}$ We too are cautious in our interpretation of these proportions, but await with interest further reports of ICS related adrenal suppression.

So, what are the conclusions to be drawn from this report? In our current state of knowledge, it would be quite wrong to suggest a major change in established practice. ICS treatment has been of immense value to literally millions of children, and other antiasthma therapy is best regarded as steroid sparing $^{18}$ rather than a true alternative to ICS. Nevertheless, we should review our practice and pay more attention to existing recommendations on the importance of stepping down as well as stepping up ICS, ${ }^{19}$ and, as ever, we must be constantly vigilant for unforeseen side effects of even the best established drugs. Whatever else we do, we must not panic and endanger the lives and wellbeing of the countless children whose respiratory and endocrine systems co-exist happily on ICS.

Department of Child Health,

GEORGE RUSSELL

University of Aberdeen, UK

1 Anonymous. Inhaled corticosteroids compared with oral prednisone in patients starting long-term corticosteroid therapy for asthma. A controlled trial by the British Thoracic and Tuberculosis Association. Lancet 1975;2: 469-73.

2 Kershnar H, Klein R, Waldman D, et al. Treatment of chronic childhood asthma with beclomethasone dipropionate aerosols: II. Effect on pituitary-adrenal function after substitution for oral corticosteroids. Pediatrics 1978;62:189-97.
3 Stiksa G, Nemcek K, Glennow C. Adrenal function in asthmatics treated with high-dose budesonide. Respiration 1985;48:91-3.

4 Mellis CM, Phelan PD. Asthma deaths in children-a continuing problem. Thorax 1977;32:29-34

5 Covar RA, Leung DY, McCormick D, et al. Risk factors associated with glucocorticoid-induced adverse effects in children with severe asthma. F Allergy Clin Immunol 2000;106:651-9.

6 Turpeinen M, Sorva R, Juntunen-Backman K. Changes in carbohydrate and lipid metabolism in children with asthma inhaling budesonide. $\mathcal{f}$ Allergy Clin Immunol 1991;88:384-9.

7 Kruszynska YT, Greenstone M, Home PD, Cooke NJ. Kruszynska YT, Greenstone M, Home PD, Cooke NJ.
Effect of high dose inhaled beclomethasone dipropionate on carbohydrate and lipid metabolism in normal subjects. Thorax 1987;42:881-4

8 Kiviranta K, Turpeinen M. Effect of eight months of inhaled beclomethasone dipropionate and budesonide on carbohydrate metabolism in adults with asthma. Thorax 1993;48: 974-8.

9 Brown HM. Nocturnal adrenal suppression in children inhaling beclomethasone dipropionate. Lancet 1986;1: 1269.

10 Law CM, Marchant JL, Honour JW, et al. Nocturnal adrenal suppression in asthmatic children taking inhaled beclomethasone dipropionate. Lancet 1986;i:942-4

11 Bisgaard H, Damkjaer NM, Andersen B, et al. Adrenal function in children with bronchial asthma treated with beclomethasone dipropionate or budesonide. $\mathcal{F}$ Allergy Clin Immunol 1988;81:1088-95.

12 Pedersen S, Fuglsang G. Urine cortisol excretion in children treated with high doses of inhaled corticosteroids: a comparison of budesonide and beclomethasone. Eur Respir f $1988 ; 1: 433-5$.

13 Lipworth BJ. Systemic adverse effects of inhaled corticosteroid therapy: a systematic review and meta-analysis. Arch Intern Med 1999;159:941-55.

14 Clark DJ, Clark RA, Lipworth BJ. Adrenal suppression with inhaled budesonide and fluticasone propionate given by large volume spacer to asthmatic children. Thorax 1996;51: $941-3$

15 Brutsche $\mathrm{MH}$, Brutsche IC, Munawar M, et al. Comparison of pharmacokinetics and systemic effects of inhaled fluticasone propionate in patients with asthma and healthy volunteers: a randomised crossover study. Lancet 2000;356: 556-61

16 Weiner P, Berar-Yanay N, Davidovich A, Magadle R. Nocturnal cortisol secretion in asthmatic patients after inhalation of fluticasone propionate. Chest 1999;116: 931-4.

17 http://www.doh.gov.uk/pdfs/pca98.pdf

18 Helms PJ. Corticosteroid-sparing options in the treatment of childhood asthma. Drugs 2000;59(suppl 1):15-22.

19 British Thoracic Society, National Asthma Campaign, Royal College of Physicians of London, et al. The British Guidelines on Asthma Management. 1995 Review and Position Statement. Thorax 1997;52:S1-S20.

\title{
7th European Forum on Quality Improvement in Health Care
}

\author{
21-23 March 2002 \\ Edinburgh, Scotland
}

We are delighted to announce this forthcoming conference in Edinburgh. Authors are invited to submit papers (call for papers closes on Friday 5 October 2001) and delegate enquiries are welcome.

The themes of the Forum are:

- Leadership, culture change, and change management

- Achieving radical improvement by redesigning care

- Health policy for lasting improvement in health care systems

- Patient safety

- Measurement for improvement, learning, and accountability

- Partnership with patients

- Professional quality: the foundation for improvement

- Continuous improvement in education and training

- People and improvement.

Presented to you by the BMJ Publishing Group (London, UK) and Institute for Healthcare Improvement (Boston, USA). For more information contact: quality@bma.org.uk or look at the website www.quality.bmjpg.com. Tel: +44 (0)20 7383 6409; fax: +44 (0)20 73736869 . 